\title{
Demographic Processes and Trends: The Case of Region Polimlje-Ibar
}

\author{
Goran Rajović $^{1, a,{ }^{*} \text {, Jelisavka Bulatović }}{ }^{2, b}$ \\ ${ }^{1}$ Vojvode Stepe 252, Belgrade, Serbia \\ E-mail address: ${ }^{a}$ dkgoran.rajovic@gmail.com \\ ${ }^{2}$ College of Textile Design, Technology and Management, Belgrade, Serbia \\ E-mail address: bjelisavka.bulatovic@gmail.com \\ *Corresponding author: dkgoran.rajovic@gmail.com
}

Keywords: Region Polimlje-lbar, demographic processes, demographic trends.

\begin{abstract}
This paper analyzes the contemporary demographic processes and trends in the case of the region Polimlje-Ibar. Population analyzed area is characterized by a steady decline in relation to the dynamics of the population Montenegro. Thus in 1948 the population of the region is seemed $26.8 \%$ of the population Montenegro and in $200319.0 \%$. The age structure of the population the region Polimlje-Ibar, due to migration and reducing birth rate is changed and takes on unfavorable characteristics - reduces the proportion of younger, while increasing the share of the elderly population. In both cases deranged age structure has feedback influence on the movement of population (size reproductive contingent), but also to all other population structure (size of the working population, the active population, schools compulsory contingent relationship serving a), which are essential for the development of population and economic activity in the region. Despite significant changes in all demographic structure of the region Polimlje-Ibar, has the characteristics of ethnically very heterogeneous environment. The current demographic situation and future demographic processes that have determined the legality of long-term demographic inertia, has become a limiting factor in the overall economic and social development.
\end{abstract}

\section{INTRODUCTION}

In the period between 1948 and 2011 in the region Polimlje-Ibar has seen significant demographic changes that are an expression of long-term trends in total and structural composition of the population. The fact is that they clearly came to the fore in the second half of the twentieth century and that were analyzed in the geographical works of many authors. In this paper the authors of this paper discusses the major demographic changes and trends resulting in the total number of inhabitants the region Polimlje-Ibar and its components (natural movement) and its structure on the basis of census data from 2003. 


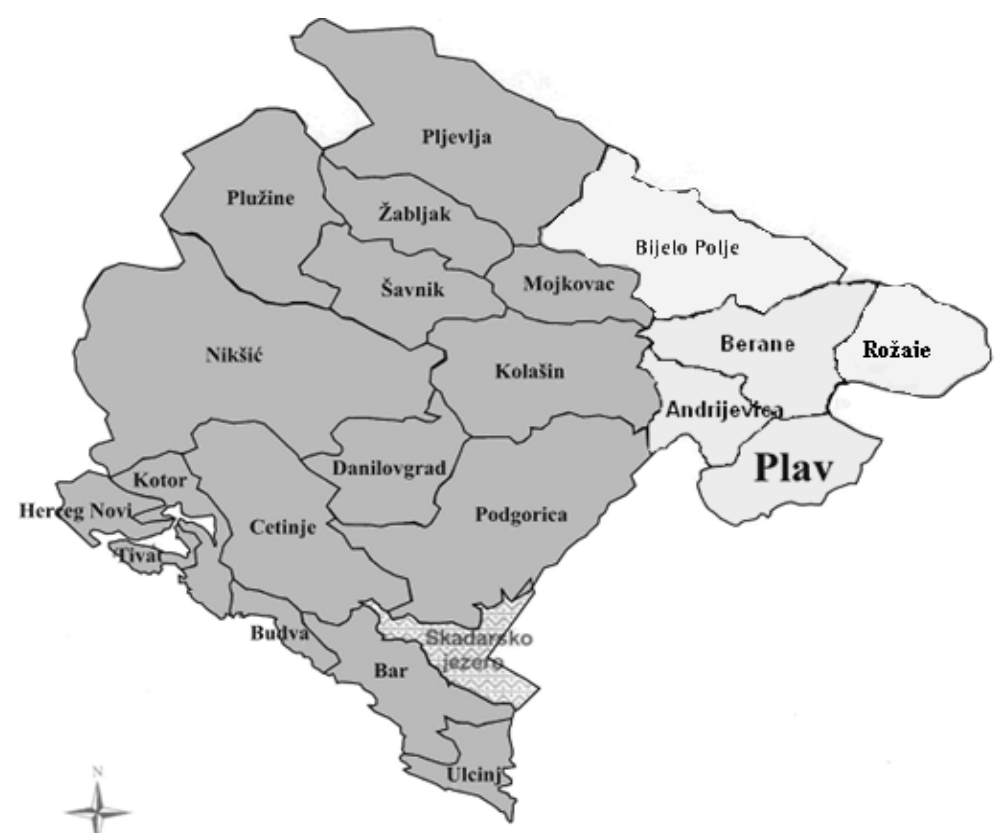

Fig. 1. Region Polimlje-Ibar on the map of Montenegro $[1,2,3]^{1}$.

\section{RESEARCH METHODOLOGY}

This work has multiple goals. First of all, the analysis of the existing literature aims to determine the number and population density of population. The next goal is to draw attention to changes the natural population movement. And finally, should point to the analysis of the structure and scope of the population. The methodology is primarily based on an analysis of the existing literature on the population the region and statistical data. From the existing literature, we used both domestic and it was published in the international literature. On this occasion of the international apostrophized in publications: Zuanna [4], Kloos et al [5], Emirhafizović [6] and Connolly et al [7]. This literature consists of monographs on population, proceedings and textbooks. Were also investigated written sources on the Internet? In the scientific explanation of concepts, applied are two methods as follows: an analytical and synthetic. Analytical methods are discussed some of the dimensions of the research subject, a synthetic whole, the relations between the subject and suggested measures deriving there from.

\section{ANALYSIS AND DISCUSSION}

Modern processes in the population development region Polimlje-Ibar, as well as projections population development in future periods (until the middle of this century) show that demographic trends are an important determinant component of the overall development of Montenegro. Our research evidence based on similar studies Živić [8] suggests that a balanced demographic development assumption of stable development of the Montenegrin state and every individual in her. Generally, we observe the demographic development in a complex interdependence and intertwining with all relevant social, economic, historical, scientific, political, cultural and other processes in the community. If sleep disorders in the population development indicate disorders, for example in economic development (which is very often the case)(see Rajović and Bulatović [9], Rajović and Bulatović [10], Rajović and Bulatović [11], Rajović and Bulatović [12], Rajović and Bulatović [13], Rajović and Bulatović [14], Rajović and Bulatović [15]), then the create strong preconditions in the destabilization of the population and overall development.

\footnotetext{
${ }^{1}$ Region Polimlje-Ibar includes the municipality of Bijelo Polje, Rožaje, Berane Petnjica, Andrijevica, Plav and Gusinje. However, as this are paper analyzes demographic trends and processes in the region relating to the period from the year 2003 that is at a time when today's territory Petnjica was part of the municipality of Berane a territory Gusinje in composition municipality Plav. The Petnjica has received municipal status in 2013, and the municipality Gusinje 2014.
} 
Table 1. Comparative population trends from 1948 to 2003

\begin{tabular}{|c|c|c|}
\hline Municipalities & 1948. & 2003. \\
\hline Andrijevica & 10.067 & 5.785 \\
\hline Berane & 27.646 & 35.068 \\
\hline Plav & 15.674 & 13.805 \\
\hline Bijelo Polje & 36.795 & 50.284 \\
\hline Rožaje & 11.047 & 22.693 \\
\hline Polimlje-Ibar & 101.229 & 127.635 \\
\hline
\end{tabular}

Source [16].

The population of the region Polimlje-Ibar is characterized by a steady decline in relation to the dynamics of the population. Thus, in 1948 the population of the region seemed $26.8 \%$ of the population Montenegro and in 2003 19.0\%. The percentage increase in the population of Montenegro amounted to 1948 - 2003.godine 43.96\%. However, some parts of Montenegro, including the region Polimlje-Ibar, indicate considerable deviations from the indicated population dynamics. Thus, the percentage increase in the population amounted in the period $1948-2003$, 26.406 inhabitants, but with a declining trend in the municipality of Andrijevica (10067-5785) and municipality Plav (15.674-13.805). The reasons for the depopulation in these municipalities are in a negative natural increase, primarily in the large emigration population from the economically underdeveloped communities. On the other hand, in the period 1948-2003, the increased population in the municipality of Bijelo Polje with 36.795 to 50.284, in the municipality of Berane with 27.646 to 35.068 in Rožaje with 11.047 to 22.693 inhabitants. Observing changes in the movement of the total population of the region Polimlje-Ibar, especially in municipalities, we can conclude that the municipalities of Berane, Bijelo Polje and R0žaje had a constant growth in the population, while municipalities Andrijevica and Plav had a continuing decline in the overall population trends.

Table 2. Areas, average density population and the number of settlements

\begin{tabular}{|c|c|c|c|}
\hline Municipalities & Area $\left(\mathrm{km}^{2}\right)$ & $\begin{array}{c}\text { The average population } \\
\text { density }\left(\mathrm{in} / \mathrm{km}^{2}\right)\end{array}$ & Number of settlements \\
\hline Andrijevica & 283 & 20.4 & 24 \\
\hline Berane & 717 & 48.9 & 66 \\
\hline Plav & 486 & 28.4 & 23 \\
\hline Bijelo Polje & 924 & 54.4 & 98 \\
\hline Rožaje & 432 & 52.5 & 26 \\
\hline Polimlje-Ibar & 2.842 & 44.9 & 237 \\
\hline \multicolumn{4}{|r}{ Source $[16]}$.
\end{tabular}

The overall population density is one of the basic demographic characteristics, indicating the spatial distribution of the population. At the observed territory, it ranges from $20.4 \mathrm{in} / \mathrm{km}^{2}$ (municipality Andrijevica), $432 \mathrm{in} / \mathrm{km}^{2}$ (municipality Rožaje), $486 \mathrm{in} / \mathrm{km}^{2}$ (Plav), $717 \mathrm{in} / \mathrm{km}^{2}$ (Berane) to 924 $\mathrm{in} / \mathrm{km}^{2}$ (municipality of Bijelo Polje). With great certainty it can be argued that such a distribution of the population has its causes in the economy does not development, but also adverse effects on the natural growth and population structure which will show the following analysis. On the territory of the region Polimlje-Ibar in five municipalities has 237 settlements. Most of the villages have the most extensive municipalities (Bijelo Polje - 98 and Berane 66), at least until the settlement have municipalities that are spread over a smaller area (Rožaje 26, Andrijevica - 24, Plav - 23). General data presented in this part of Montenegro, can serve as a good framework to display the size of the selected model in the context of global events. The investigated region is in the group not developed regions, where due to dispersion urban - height structure has been a significant disproportion between the size and growth trends municipalities (Bijelo Polje, Berane, Rožaje, Andrijevica and Plav) and other settlements in the studied area. As a scattered settlements, structured compacted fragments (hamlets), remote and scattered throughout the territory of the corresponding region, this 
part of Montenegro the an interesting and distinctive way, fits in a systematic picture of the village of Montenegro and Serbia. "Because it takes such an environment supplemented by new and more effective activities, thus achieving a more balanced economic development at the country level, which is one of the are primary objectives of local economic development. Positive examples of local and regional development, with well-defined strategy, have been reported in the areas of Baden Werttenberg in Germany, Lorraine in France, Westphalia in the UK, Veneto, Friuli in Italy and our neighboring Slovenia. This concept of development is practical, since it includes all those who want to cooperate, does not cost much and gives results, which is of particular importance for the underdeveloped countries" [17].

Table 3. Population growth for 2008

\begin{tabular}{|c|c|c|c|c|c|}
\hline Municipalities & Newborns & $\%$ & They died & $\%$ & $\begin{array}{c}\text { Natural } \\
\text { growth }\end{array}$ \\
\hline Andrijevica & 43 & 2,3 & 72 & 6.5 & -29 \\
\hline Berane & 479 & 25.8 & 332 & 29.9 & 147 \\
\hline Plav & 156 & 8.5 & 131 & 11.8 & 25 \\
\hline Bijelo Polje & 722 & 39.0 & 438 & 39.5 & 284 \\
\hline Rožaje & 453 & 24.4 & 137 & 12.3 & 316 \\
\hline Polimlje-Ibar & 1.853 & 100 & 1.110 & 100 & 801 \\
\hline
\end{tabular}

Source [18].

Viewed separately, by municipality, we can determine the legality of the individual that is the negative natural population growth is expressed in small and underdeveloped municipalities (Andrijevica). Spatial large municipalities (Bijelo Polje, Berane) have positive population growth, except the municipalities of Rožaje and Plav, which are spatially smaller but also have positive population growth, because in them the majority of the population are Muslim-Bosniak population whose birth rate more than with other ethnic groups [19]. Municipality of Bijelo Polje, Berane and Rožaje accounted for $89.2 \%$ of live births in the territory of the region Polimlje-Ibar, while at the same time their participation in the number of deaths was $81.7 \%$. Our research evidence based on similar studies Medojević and Milosavljević [19], points during 2008 according to the Statistics Bureau of Montenegro [18] was concluded a total of 778 of marriages, while in the same period, 115 divorced marriages. The most of marriages were concluded in the municipality of Bijelo Polje 313, followed by Berane - 198, Rožaje - 177, Plav - 76 and Andrijevica - 14. Divorced marriages in this period, most of them were in municipality Rožaje - 62 and Berane 31. While they are lowest number of divorces in the Municipalities of Andrijevica 1, or in municipality Plav not established during in 2008 divorced marriages.

The age structure of the population of the region Polimlje-Ibar, due to migration and reducing the birth rate is changed and takes on unfavorable characteristics - reduces the proportion of younger, while increasing the share of the elderly population (see Rajović [20], Rajović and Bulatović [21]. The age structure of the population the region Polimlje-Ibar, due to migration and reducing birth rate is changed and takes on unfavorable characteristics - reduces the proportion of younger, while increasing the share of the elderly population. In both cases deranged age structure has feedback influence on the movement of population (size reproductive contingent), but also to all other population structure (size of the working population, the active population, schools compulsory contingent relationship serving a), which are essential for the development of population and economic activity in the region (see Rajović [22], Rajović [23]). 
Table 4. Population age structure

\begin{tabular}{|c|c|c|c|c|c|c|c|c|c|c|}
\hline Municipalities & $0-19$ & $\%$ & $20-39$ & $\%$ & $40-59$ & $\%$ & $60-79$ & $\%$ & $\begin{array}{c}80 \text { and } \\
\text { more }\end{array}$ & $\%$ \\
\hline Andrijevica & 1.532 & 3.7 & 1.524 & 4.1 & 1.354 & 4.8 & 1.096 & 6.1 & 159 & 9.5 \\
\hline Berane & 10.593 & 25.9 & 10.160 & 27.5 & 8.016 & 28.2 & 5.499 & 30.6 & 504 & 30.2 \\
\hline Plav & 4.816 & 11.9 & 3.573 & 9.7 & 3.000 & 10.5 & 2.126 & 11.8 & 234 & 13.9 \\
\hline Bijelo Polje & 15.409 & 37.6 & 14.680 & 39.7 & 11.598 & 40.7 & 7.160 & 39.8 & 608 & 36.4 \\
\hline Rožaje & 8.593 & 20.9 & 7.035 & 19.0 & 4.511 & 15.8 & 2.099 & 11.7 & 168 & 10.0 \\
\hline Polimlje-Ibar & 40.943 & 100 & 36.972 & 100 & 28.479 & 100 & 17.980 & 100 & 1.673 & 100 \\
\hline
\end{tabular}

Middle-aged population dominates in the region Polimlje-Ibar with 65.451 inhabitants $(50.1 \%)$, of which $36.972(29.0 \%)$ belongs to the so-called younger middle-aged population (20-39 years), while $28.479(22.3 \%)$ belongs to the so-called older middle-aged population (40-59 years). The contingent of young people (0-19 years) counts $40.943(32.1 \%)$ of the population living on the concerned territory. The lowest representation in the age structure seems contingent old population (60 and over) with 19.653 inhabitants $(15.4 \%)$ of the total population.

Ageing index represents the ratio of the population aged 60 and over, according to population under 20 years. If its value is less than 0.40 the population is still young, and if it is greater than 0.40 populations shows signs of aging. The aging index population region Polimlje-Ibar in 2003 amounted to 0.48 . Thus, the population of the region is in the process of demographic aging, manifested increase in the percentage of aged and older adult at the expense of the young [25]. Relationship between the big age groups in most municipalities is identical to the relative age group in the entire region (the largest is the middle-aged population, followed by the young and the end is at least numerically the aging population) (Table 4).

Table 5. Gender structure of population

\begin{tabular}{|c|c|c|c|c|c|c|}
\hline Municipalities & Home & $\%$ & Femme & $\%$ & Total & $\%$ \\
\hline Andrijevica & 2.941 & 4.8 & 2.844 & 4.5 & 5.785 & 4.5 \\
\hline Berane & 17.545 & 25.1 & 17.523 & 27.4 & 35.068 & 27.5 \\
\hline Plav & 6.821 & 11.0 & 6.984 & 11.0 & 13.805 & 10.8 \\
\hline Bijelo Polje & 25.227 & 40.7 & 25.057 & 39.3 & 50.284 & 39.4 \\
\hline Rožaje & 11.357 & 18.4 & 11.336 & 17.8 & 22.693 & 17.8 \\
\hline Polimlje-Ibar & 63.891 & 100 & 63.744 & 100 & 127.635 & 100 \\
\hline
\end{tabular}

Source [16].

In the area of the region Polimlje-Ibar live 127.635 inhabitants, from that them 63.891 (50.05\%) were male, while $63.744(49.5 \%)$ women. We see that the relationship between men and women in this area almost identical, which is extremely important during the fertile period as an even chance of having both men and women to find a partner for marriage. A slightly higher number of men than women have the municipalities of Andrijevica, Berane, Bijelo Polje and Rožaje. Women are more numerous than men in Plav. The entire territory of the observed maximum is population of the municipality of Bijelo Polje and Berane, and thus the role of men and women from these municipalities greatest [19].

The rate of masculinity shows the number of men per 1.000 women. According to the census of 2003 , the rate of masculinity in the region amounted to $1002.3 \%$. The rate of femininity shows the number of women per 1.000 men and was in the analyzed period, 997.6. This may be due to male emigration or immigration of female population. Given, the still narrow framework of economic development, employment of female labor force is going far more slowly than men's, because of the influence of the structure of economic activity, which no longer requires male labor force. Taking for example, that in the region there are favorable conditions for the development of textile industry and handicrafts, which would be the most engaged female workforce, this production can significantly affect the increase in employment of women. The engagement of the female labor 
force in the economy, it would have more supplementary character that would ensure existential security of women in society and in the family [26].

Within the factors that may affect the development of the population, educational characteristics have an important place. Perceiving the educational characteristics of the population, in addition to the independent value that this factor has, may indicate the effects it has on economic development [27].

Table 6. Illiterate population aged 15 years and over

\begin{tabular}{|c|c|c|c|}
\hline Municipalities & Total & Illiterate & $\%$ \\
\hline Andrijevica & 4.690 & 170 & 0.8 \\
\hline Berane & 27.318 & 611 & 0.6 \\
\hline Plav & 10.316 & 646 & 0.7 \\
\hline Bijelo Polje & 39.145 & 1.312 & 1.3 \\
\hline Rožaje & 16.266 & 568 & 0.6 \\
\hline Polimlje-Ibar & 97.735 & 3.307 & 100 \\
\hline
\end{tabular}

Source[28].

Literacy is one of the basic indicators of the educational structure of the population. According to the results of the census of 2003, there were in the municipality of Berane $0.6 \%$, the municipality of Andrijevica $0.8 \%$ municipality Plav $0.7 \%$ municipality Rožaje $0.6 \%$ and the municipality of Bijelo Polje $1.3 \%$ of the illiterate population, aged over 15 years compared to the total illiterate population in the concerned area. It should be noted that education was covered, mostly men, while female literacy of the population individually.

Table 7. Structure of the population by educational attainment

\begin{tabular}{|c|c|c|c|c|c|c|c|c|c|c|}
\hline Municipalities & 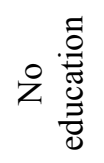 & $\%$ & 坣. & $\%$ & 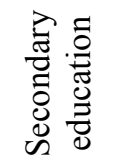 & $\%$ & 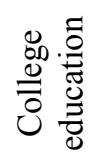 & $\%$ & 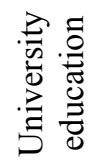 & $\%$ \\
\hline Andrijevica & 313 & 5.5 & 1.367 & 4.6 & 1.511 & 4.5 & 190 & 2.0 & 145 & 3.4 \\
\hline Berane & 1.070 & 18.7 & 7.837 & 26.5 & 8.335 & 24.7 & 1.362 & 14.3 & 1.511 & 36.0 \\
\hline Plav & 862 & 15.1 & 3.080 & 10.5 & 9.219 & 27.4 & 307 & 3.2 & 497 & 11.8 \\
\hline Bijelo Polje & 2.460 & 43.0 & 11.649 & 39.5 & 11.598 & 34.4 & 7.160 & 75.1 & 1.418 & 33.7 \\
\hline Rožaje & 1.015 & 17.7 & 5.576 & 18.9 & 3.029 & 9.0 & 514 & 5.4 & 635 & 15.1 \\
\hline Polimlje-Ibar & 5.720 & 100 & 29.509 & 100 & 33.692 & 100 & 9.533 & 100 & 4.206 & 100 \\
\hline
\end{tabular}

Source [28].

Level of education is another important indicator of the educational structure of the population. Although the obvious positive changes in the region though formal education is not at a high enough level. According to the census of 2003, without any education were 5.720 , or $6.9 \%$ of the total population aged 15 and over. With primary school education was 29.509 or $35.7 \%$ of the population with secondary education was 33.692 or $40.8 \%$, with higher education 9.533 or $11.5 \%$ and university 4.206 or $5.09 \%$ of the population aged 15 and over.

This educational structure of the population is unfavorable for any modernization of the economy in the region. Its alleviation and overcoming a prerequisite are for the revitalization and sustainable development. Based on these data, it cannot be judged on the low interest of the population of this part of Montenegro, to be educated or to educate their children. The cause of the relatively small number of people with college and university education lies certainly in poor material resources, but also in the fact that many after completing secondary education are leaving the region due to the inability to get a job in him [29-30].

According to the census of 2003 in the Region Polimlje-Ibar have 40.070 active populations (31.4\%) of the total population. Persons with personal incomes has a total of $18.166(14.2 \%)$, supported population has $59.754(46.8 \%)$, while people working abroad has $675(0.5 \%)$ of the total population. 
Table 8. Active, persons with personal income and the supported population

\begin{tabular}{|c|c|c|c|c|c|c|c|c|}
\hline Municipalities & $\begin{array}{c}\text { Active } \\
\text { population }\end{array}$ & $\%$ & $\begin{array}{c}\text { With } \\
\text { personal } \\
\text { income }\end{array}$ & $\%$ & $\begin{array}{c}\text { The } \\
\text { supported } \\
\text { population }\end{array}$ & $\%$ & $\begin{array}{c}\text { Working } \\
\text { Abroad }\end{array}$ & $\%$ \\
\hline Andrijevica & 2.320 & 4.7 & 1.079 & 5.9 & 2.365 & 4.0 & 21 & 3.1 \\
\hline Berane & 13.477 & 27.5 & 5.924 & 32.6 & 15.591 & 26.1 & 106 & 15.8 \\
\hline Plav & 4.561 & 9.3 & 1.886 & 10.4 & 7.249 & 12.1 & 109 & 16.1 \\
\hline Bijelo Polje & 20.607 & 42.0 & 7.170 & 39.5 & 22.239 & 37.2 & 268 & 39.7 \\
\hline Rožaje & 8.105 & 16.5 & 2.107 & 11.6 & 12.310 & 20.6 & 171 & 25.3 \\
\hline Polimlje-Ibar & 49.070 & 100 & 18.166 & 100 & 59.754 & 100 & 675 & 100 \\
\hline
\end{tabular}

Source [31].

The active population is most numerous in the municipalities of Bijelo Polje $(41.0 \%$ of the total active population of the municipality) and Berane $38.4 \%$. The supported are population most numerous in municipalities Andrijevica ( $40.8 \%$ of the total population of the municipality), Berane (44.5\%), Bijelo Polje (44.2\%), Plav (52.5\%), and in Rožaje (54.2\%). With personal are incomes in this region most people municipalities Berane (16.8\%) and Bijelo Polje (14.2\%). The persons temporarily working abroad in this region has little. Most of them were from the municipalities of Bijelo Polje ( $0.5 \%$ of the total population of the municipality), Rožaje $(0.7 \%)$ and Blue $(0.8 \%)$. According to Medojević and Milosavljević [19] most of the employed population in are the major industrial centers of Bijelo Polje - $8.628(17.5 \%)$ and Berane - $6.092(12.4 \%)$. Least employees in small and municipalities without are strong economy Andrijevica - 537 (1.1\%). The average salary in the analyzed area of Montenegro is 371 euro. As with employment and earnings in the forefront population in developed economic centers for example Rožaje ( $€$ 382). Least for-work residents have poorer municipalities and municipalities in which the economy is in bad shape Plav (332€), Andrijevica (€ 336) and Bijelo Polje (353€).

In each of the national community it is very important what kind of differences there are in the demographic structure of the population of some national communities. "Namely, examination of demographic characteristics in different ethnic groups, especially if it includes people of various nationalities within the same country or is done with the nationalities living in the same territory cohabitation, represents special interest because it allows consideration of differences in demographic structures and trends, the factors to which they are influenced and the tendency continued existence, mitigate or increase the differences in demographic characteristics between different nationalities [32].

According to 2003 census region Polimlje-Ibar is ethnically heterogeneous territory. Share Serbs in the total population of the region is $34.6 \%$ (44.128 inhabitants). The most numerous ethnic group in the analyzed area after Serb are Bosnians with a share of 33.3\% (42.476 inhabitants), after which follow Montenegrins 16.1\% (20.545 inhabitants), Muslims from 9.8\% (12.545 inhabitants), while Albanians account for $2.9 \%$ (3,727 inhabitants).

Table 9. The ethnic structure of the population

\begin{tabular}{|c|c|c|c|c|c|c|c|c|c|c|}
\hline 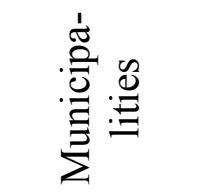 & $\begin{array}{l}n \\
\stackrel{0}{0} \\
\tilde{n}\end{array}$ & $\%$ & 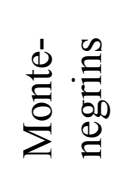 & $\%$ & 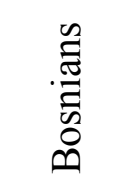 & $\%$ & $\frac{\mathscr{n}}{\stackrel{\Xi}{\Xi}}$ & $\%$ & 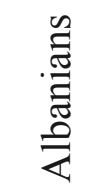 & $\%$ \\
\hline Andrijevica & 4.027 & 9.1 & 1.454 & 7.1 & - & - & 8 & 0.1 & - & - \\
\hline Berane & 16.309 & 37.1 & 8.950 & 43.6 & 5.662 & 13.3 & 2.301 & 18.3 & - & - \\
\hline Plav & 2.613 & 5.9 & 765 & 3.7 & 6.809 & 16.0 & 788 & 6.3 & 2.719 & 73 \\
\hline Bijelo Polje & 20.275 & 45.9 & 8.936 & 43.5 & 11.377 & 26.8 & 7.938 & 63.3 & - & - \\
\hline Rožaje & 904 & 2.0 & 440 & 2.1 & 18.628 & 43.9 & 1.510 & 12.0 & 1.008 & 27.0 \\
\hline Polimlje-Ibar & 44.128 & 100 & 20.545 & 100 & 42.476 & 100 & 12.545 & 100 & 3.727 & 100 \\
\hline
\end{tabular}

Source [33]. 
The Serbian population is most numerous in Andrijevica $(70.0 \%$ of the total population of the municipality), Berane (46.5\%) and Bijelo Polje (40.3\%). The second highest number of Serbs is represented in Plav (18.9\%). Montenegrins most people make in Berane (25.5\%), Andrijevica (25.0\%), and Bijelo Polje (17.7\%). Bosniak population majority does in the municipalities of Plav (49.3\% of the total population), and in Rožaje (82.0\%). In addition to these municipalities Bosnians are still serious issue represented in Berane (16.0\%) and Bijelo Polje (22.6\%). Muslims do not make up the majority in any municipality, but are present in Berane (6.5\%), Bijelo Polje (15.8\%), Plav $(5.7 \%)$, and in Rožaje (6.6\%). As Muslims and Albanians are not in the majority in any municipality, but most of them has in the municipalities of Plav (19.7\%), and in Rožaje (4.4\%) [19].

Table 10. The confessional structure of the population

\begin{tabular}{|c|c|c|c|c|c|c|c|c|c|c|}
\hline 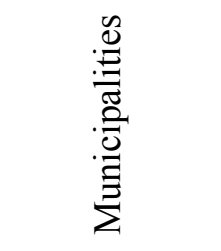 & 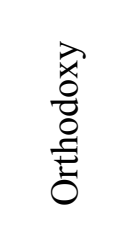 & $\%$ & 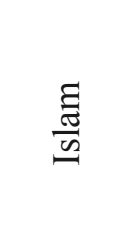 & $\%$ & 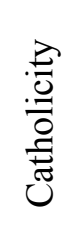 & $\%$ & 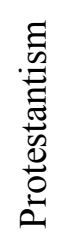 & $\%$ & 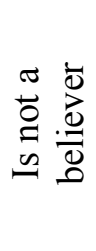 & $\%$ \\
\hline Andrijevica & 5.634 & 8.8 & 10 & 0.0 & 6 & 2.2 & - & - & 6 & 2.6 \\
\hline Berane & 24.873 & 38.8 & 8.994 & 14.9 & 75 & 27.3 & 13 & 92.9 & 117 & 51.6 \\
\hline Plav & 3.348 & 5.2 & 10.246 & 16.9 & 98 & 35.6 & - & - & 3 & 1.3 \\
\hline Bijelo Polje & 28.996 & 45.3 & 19.964 & 33.0 & 87 & 31.6 & 1 & 7.1 & 100 & 44.1 \\
\hline Rožaje & 1.245 & 1.9 & 21.252 & 35.2 & 9 & 3.3 & - & - & 1 & 0.4 \\
\hline Polimlje-Ibar & 64.096 & 100 & 60.466 & 100 & 275 & 100 & 14 & 100 & 227 & 100 \\
\hline
\end{tabular}

The confessional structure of the region Polimlje-Ibar follows general trends in appearing and the ethnic composition of the population. Census 2003 shows that in the analyzed territory lived 44.096 or $50.2 \%$ of the Orthodox faith in relation to the total population, followed by 60.466 or $47.4 \%$ of members of the Islamic faith, the faith of members catholicity 275 or $0.2 \%$, members Protestantism 14 or $0.01 \%$, while 227 or $0.2 \%$ of the population and stated that is not a believer. "This drastic difference in the percentage share of certain religions in the total population is caused by differences in the rates of natural increase among the members of Islamic and Orthodox faiths. High rates of population growth in the Muslim population, low among the members of other communities, primarily in Serbian, which is present and prominent emigration [35]. Our research evidence based on similar studies Rudić and Stepić [36] indicates that this is an area of vital geostrategic importance for Montenegro and should pay more attention to building a spirit of tolerance and coexistence of different ethnic communities. In fact, the overall development of the region Polimlje-Ibar would have to be viewed through the prism of a strong integrated socioeconomic and cultural development which would constitute a guarantee of prosperity Serbian, Montenegrin, Bosnaik, Muslim, ethnic Albanian population in this region.

Table 11. Population by marital status

\begin{tabular}{|c|c|c|c|c|c|c|c|c|c|}
\hline Municipalities & Total & $\begin{array}{c}\text { Not } \\
\text { married }\end{array}$ & $\%$ & Married & $\%$ & Unmarried & $\%$ & Married & $\%$ \\
\hline Andrijevica & 4.690 & 988 & 5.4 & 1.207 & 4.4 & 575 & 4.3 & 1.182 & 4.3 \\
\hline Berane & 27.318 & 4.886 & 26.9 & 7.652 & 28.0 & 3.462 & 26.1 & 7.626 & 27.7 \\
\hline Plav & 10.316 & 1.895 & 10.5 & 2.899 & 10.7 & 1.454 & 11.0 & 2.940 & 10.7 \\
\hline Bijelo Polje & 39.145 & 7.363 & 40.6 & 10.912 & 40.0 & 5.275 & 39.8 & 11.034 & 40.0 \\
\hline Rožaje & 16.266 & 3.011 & 16.6 & 4.622 & 16.9 & 2.498 & 18.8 & 4.772 & 17.3 \\
\hline Polimlje-Ibar & 97.735 & 18.143 & 100 & 27.292 & 100 & 13.264 & 100 & 27.554 & 100 \\
\hline
\end{tabular}

Data on marital status are presented for the population aged 15 and over and refer to the legal marital status at the time of the census. Another very worrying fact is that the number of single 
persons in the territory of the region. According to the National Statistical Office of Montenegro [36] in the municipality of Andrijevica, a total of 988 single men, single women 575, Municipality Berane 4.886 - 3.462, of the Municipality Plav 1.895 - 1.454, the municipality of Bijelo Polje 7.363 - 5.275 and 3.011 - 2.498 of the Municipality Rožaje. The biggest numbers of people who not get married mainly in mountainous rural settlements of the region in which people generally have no fixed income. By reducing the number of single significantly enhances the demographics of the entire analyzed territory. Natural movement of population cannot be successfully explained beyond existing social and economic conditions in which the population is observed ( see Rajović and Bulatović [38], Rajović and Bulatović [39], Rajović and Bulatović [40]). According to data of the Statistical Office of Montenegro [36] in the municipality of Andrijevica a total of 1.207 married men married women's 1.182, the municipality of Berane 7.652 - 7.626, of the Municipality Plav 2.899 - 2.940, the municipality of Bijelo Polje 10.912 - 11.034 and Municipalities of Rožaje 4.6224.772. According to Valdevit [41] in the highly developed industrialized countries of the West married women have lower activity rates than the unmarried. Widows and divorced have lower activity rates than the unmarried, but still significantly higher than married women and that if viewed at the same age groups. When it comes to choosing between employment outside the home and raising children, it is always a personal choice women, but it is a very important value composition, because if a professional career is considered more important, the Balkan region is mostly so, many women choose to work outside the home. The woman is necessary to create conditions for adequate choice, because the problems faced by the family in the upbringing and education of children are neither small nor socially insignificant. Mother after children enter the workforce accepting rather shorter time jobs, which allows them to better reconcile family and professional life.

Table 12. Families according to the type and number of children under the age of 25 years

\begin{tabular}{|c|c|c|c|c|c|c|c|c|c|c|}
\hline Municipalities & Total & $\begin{array}{c}\text { No } \\
\text { children }\end{array}$ & $\%$ & $\begin{array}{c}\text { With } \\
\text { children }\end{array}$ & $\%$ & 1 & 2 & 3 & 4 & $\begin{array}{c}5 \text { and } \\
\text { more }\end{array}$ \\
\hline Andrijevica & 1.467 & 279 & 4.9 & 895 & 4.2 & 398 & 427 & 268 & 66 & 29 \\
\hline Berane & 8.927 & 1.686 & 29.5 & 5.799 & 27.5 & 2.257 & 2.529 & 1.693 & 557 & 205 \\
\hline Plav & 3.289 & 637 & 11.1 & 2.161 & 10.3 & 721 & 753 & 653 & 352 & 173 \\
\hline Bijelo Polje & 12.684 & 2.369 & 41.4 & 8.400 & 39.9 & 3.066 & 3.502 & 2.536 & 880 & 331 \\
\hline Rožaje & 5.268 & 752 & 13.1 & 3.814 & 18.1 & 1.038 & 1.232 & 1.251 & 634 & 361 \\
\hline Polimlje-Ibar & 31.635 & 5.723 & 100 & 21.069 & 100 & 7.480 & 8.443 & 9.015 & 2.489 & 1.099 \\
\hline \multicolumn{10}{|c}{ Source $[42]}$.
\end{tabular}

According to data of the Statistical Office of Montenegro [42] in the municipality of Andrijevica, a total of 279 families without children and 895 families with children, municipality Berane 1.6865.799, Municipalities of Plav 637- 2.161, the municipality of Bijelo Polje $2.369-8.400$ and Municipalities of Rožaje 752-3.814. In addition to reducing the number of children in the family, more and more so-called no complete families, i.e. single - parent families. Most do not complete families are mainly held by women. It can be seen in Table 12 that the number of families with one child amounts to 7.480, with two children -8.443 , with three children -9.015 , with four children 2.489 and with five or more children 1.099. These trends certainly affect the economic activity and the problems associated with raising children, which cannot be only a problem of the individual but the whole community.

Intensive social development of Montenegro after the Second World War, primarily driven by cause and associated processes of industrialization and urbanization has resulted in a number of structural changes at all social levels. According to Đorđević [43] as part of these changes, there has been a radical change, as functions, and kinship organization of the household. The process of transition of households was necessary and legitimate in the circumstances of contemporary life. However, depending on the degree of social development, but also from the inherited customs and norms, different were the pace of change, and, accordingly, the achieved level of transition in certain areas. Compared to the developed countries of Europe, in Montenegro this process started much later, but 
the changes were so intense, with great territorial diversity. In the area of Montenegrin households are now fragmented and at an average population size similar to the European form, while on the territory of the region Polimlje-Ibar still represented multigenerational family community.

Table 13. Number of households and dwellings

\begin{tabular}{|c|c|c|c|c|}
\hline Municipalities & $\begin{array}{c}\text { Number } \\
\text { households }\end{array}$ & $\%$ & $\begin{array}{c}\text { Number } \\
\text { dwellings }\end{array}$ & $\%$ \\
\hline Andrijevica & 1.789 & 5.4 & 2.920 & 7.2 \\
\hline Berane & 9.623 & 29.0 & 11.948 & 29.6 \\
\hline Plav & 3.535 & 10.7 & 4.952 & 12.3 \\
\hline Bijelo Polje & 13.288 & 40.0 & 15.028 & 37.2 \\
\hline Rožaje & 5.004 & 14.9 & 5.515 & 13.7 \\
\hline Polimlje-Ibar & 33.239 & 100 & 40.363 & 100 \\
\hline
\end{tabular}

According to data of the Statistical Office of Montenegro [43] on the territory of the region Polimlje-Ibar is total 33.239 households, i.e., the total number of dwellings was 40.363. Observed by municipalities: Andrijevica 1.789-2.920, Berane 9.623-11.948, Plav was 3.535- 4.952, Bijelo Polje 13.288 - 15.028 and Municipalities of Rožaje 5.004 - 5.515. The average household in the region Polimlje-Ibar has 3.8 members.

Montenegro is in the past half century has experienced a number of radical changes in all fields of social life. Periods of development and periods of great economic are political and social crisis. All these historical changes affected the everyday life of our households which also had its ups and downs. Under the influence of numerous improving, but also destabilizing factors in the observed period, households have gradually changed their structure and population size. The changes, however, are not equal effect throughout the territory of Montenegro. Uneven pace of socioeconomic development, different cultural and historical past, as well as demographic transition, influenced the formation of large regional differences in the average size of households in Montenegro [43].

\section{INSTEAD OF A CONCLUSION}

Our research evidence based on similar studies Nimwegen et al [45], Wertheimer-Baletić [46], Bongaarts [47], Vasilyeva and Theme [48], instead points to the following conclusions:

1. Knowledge of demographic resources and the basic processes and trends in a specific area of extreme importance for the planning of social and economic development. The basic demographic processes in northern Montenegro in the last twenty years are depopulation and the aging of the population and, therefore, Andrijevica and Plav in the analyzed territory was constantly decreasing population and a reduction in young and old increase the contingent of the population.

2. However, these processes do not occur with the same intensity in all parts of the region. So we recorded an increase in population during the period 1948-2003. In the municipalities of Berane, Bijelo Polje and Rožaje. In general, profound changes in contemporary society have led to individual needs, on the one hand, and the needs of society, on the other hand, in terms of demographic reproduction do not coincide.

3. The aging population necessarily leading to pressure on the social system which is likely to manifest itself further by extending the age limit for retirement. As a result, such a process leads to subsequent entry of young people into the labor market, and therefore a smaller number who would pay contributions. It all leads to the later starting a family, or staying in one child, which adversely affects the rate of natural increase. 
4. Comprehensive reform of the social security system would open a space for young people entering the labor market which would in itself lead to improvement of their social and material position and more frequent decision to found a family. Also, the reform of the university system that would allow an even distribution of academically trained by branches of the economy. And of course, investment in infrastructure (see Rajović and Bulatović [49]) and attracting foreign investments in rural areas would lead to a further slowdown in internal migration and the degradation potential of the Montenegrin interior.

Letting the spontaneous flow of current demographic phenomena and processes increasingly sharpens not only an economic but also a social crisis, the crisis of the family and the general crisis of life in Montenegro. Urgent turnaround, primarily to the knowledge of the real demographic situation and its economic, social, health and other consequences for the life of the people, the inevitable assumption of overall development. Because the population is an important factor of development, component production is the development potential of the country, not just a consumer. The current demographic are situation and future demographic processes that have determined the legality of long-term demographic inertia but become limiting factor in the overall economic and social development.

\section{References}

[1] Regional Business Centre Berane (2004), Profile municipality of Berane, Information on: http://www.nasme.me (10.09 2015).

[2] Regional Business Centre Berane (2004), Profile municipality of Plav, Information on: http://www.nasme.me (12.09 2015).

[3] G. Rajović, J. Bulatović, Some geographical factors economic development of rural areas in the manicipality of example Andrijevica(Montenegro), Russian Journal of Agricultural and Socio Economic Sciences.5(5) (2012) 3-16.

[4] G. Dalla Zuanna, Social mobility and fertility, Demographic Research. 17(17)(2008) 441.

[5] H. Kloos, R. Correa-Oliveira, D.C.D. Reis, E.W. Rodriguez, L.A.S., Monteiro, A. Gazzinelli, The role of population movement in the epidemiology and control of schistosomiasis in Brazil: a preliminary typology of population movement, Memórias do Instituto Oswaldo Cruz. 105(4)(2010) 578-586.

[6] M. Emirhafizović, The impact of immigration on demographic trends of the European Union, with particular reference to Austria, Godišnjak Fakulteta političkih nauke. (5-6)(2010) 193-207.

[7] S.Connolly, M. Rosato, D. O'Reilly, The effect of population movement on the spatial distribution of socio-economic and health status: Analysis using the Northern Ireland mortality study. Health \& place. 17(4) (2010) 1007-1010.

[8] D. Živić, Modern tendencies in the development of the Croatian population. Diacovensia. $11(2)(2003) 253-279$.

[9] G. Rajović, J. Bulatović, Agricultural Areas and Forests: The Case Regions Polimlje-Ibar. Journal of Agriculture and Sustainability. 2(2)(2013) 178-195.

[10] G. Rajović, J. Bulatović, Status and perspectives plant production: the case regions PolimljeIbar, Annals of Plant Sciences. 2(7)(2013).

[11] G. Rajović, J. Bulatović, Geographical View on Agricultural Land and Structural Changes Plant Production Region POLIMLJE - IBAR, International Research Journal of Life Sciences. 1(2)(2013) 1-18.

[12] G. Rajović, J. Bulatović, Geography a View on Potentials Livestock Overviewed with Aspects of Production Healthy Food: The Case Region Polimlje-Ibar, Applied Journal of Hygiene. 2(3) (2013) 15-24. 
[13] G. Rajović, J. Bulatović, Status and Perspectives Livestock Production: The Case Region Polimlje-Ibar, International Letters of Natural Sciences. 6(2014) 57-68.

[14] G. Rajović, J. Bulatović, Structural changes livestock production: Case study region PolimljeIbar, Vestnik OrelGAU. 1(46)(2014) 3-13.

[15] G. Rajović, J. Bulatović, Some aspects of the geographical view of the production of healthy food - Good from Montenegro with reference to creating a brand: Case of the region Polimlje-Ibar, World Scientific News. 11(2015) 81-91.

[16] Statistical Office of Montenegro, Census of Population, Households and Dwellings 2003, Book 9. Podgorica, 2005.

[17] B.Vojnović, D. Riznić, S. Borić, The importance of defining a regional development strategy in building a competitive economy, Industrija 4(2009) 61.

[18] Statistical Office of Montenegro, Data by municipalities for 2008, Podgorica, 2008.

[19] J. Medojević, S. Milosavljević, Demographic trends and processes in the area north-west of Montenegro, 2003, Information on: http://www.academia.edu (09.09 2015).

[20] G. Rajović, Rural settlement Gnjili Potok as a reflection of the socio-economic conditions, Istraživanje i razvoj. 15( 32-33)(2009)75-77.

[21] G. Rajović, J. Bulatović, Analysis of Change in Population Structure: The Case Northeastern Montenegro, Journal of Studies in Social Sciences. 2(1)(2013) 1 - 30.

[22] G. Rajović,Agricultural changes on incidence depopulation and comparatively priority and limitations for evolution agrarian in North-eastern Montenegro, Ekonomika. 55(6)(2009) 33-44.

[23] G.Rajović, Important social factors for development of agriculture in North-Eastern Montenegro, Ekonomika. 57( 2)(2011) 62-72.

[24] Statistical Office of Montenegro, Census of Population and Housing 2003, Book 2, Podgorica, 2004.

[25] G. Rajović, J. Bulatović, Some economic-geographic factors development of the example rural areas northeastern Montenegro, Russian Journal of Agricultural and Socio - Economic Sciences. 9(9)(2013) 3-20.

[26] G. Rajović, J. Bulatović, Socio economic and geographical factors of development-Study Case: Cities Berana, Andrijevica and Plava, Journal for Geography. 7(1)(2013) 49 - 68.

[27] G. Rajović, D. Rajović, Natural and social economic characteristics of rural settlements Gnjili Potok, "The Agency PC system", Belgrade,2010.

[28] Statistical Office of Montenegro, Census of Population, Households and stanova2003 year, Book 4, Podgorica,2005.

[29] G. Rajović, Demographic characteristics of the modern labour migration from Montenegro to Denmark, GeoScape. 6( 1-2)(2011) 2-10.

[30] G. Rajović, Organization and Activities of Migrants from Serbia and Montenegro in Denmark: a Case Study, European Geographical Studies. 6(2)(2015) 92-110.

[31] Statistical Office of Montenegro, Census of Population, Households and Dwellings 2003, Book 5, Podgorica, 2005.

[32] M. Sentić, D. Breznik, Demographic tests and nationality, Naše teme 8(9)(1965).

[33] Statistical Office of Montenegro, Census of Population and Housing 2003, Book 1, Podgorica,2004. 
[34] Statistical Office of Montenegro, Census of Population, Households and Dwellings 2003, Book 3, Podgorica, 2004.

[35] E. Đ. Đoković, Ethnic and religious structure of Tutin municipality, Glasnik Srpskog geografskog drustva. 83(1) (2003) 73-78.

[36] V. Rudić, M. Stepić, Ethnic Changes in the Raška region after the Second World War, the ethnic composition of the population of Serbia and Montenegro and the Serbs in the Socialist Federal Republic of Yugoslavia, Book 1 "ethnic area of the Serbs", Faculty of Geography, Belgrade, 1993.

[37] Statistical Office of Montenegro, Census of Population, Households and Dwellings 2003, Book 12, Podgorica, 2004.

[38] G. Rajović, J. Bulatović, Movement population in the second of XX and beginning of XXI century: The Case northeastern Montenegro, Russian Journal of Agricultural and Socio - Economic Sciences. 1(13)(2013) 66-79.

[39] G. Rajović, J. Bulatović, Geographic Favor of Analyzing Rural Space: The Case Rural Local Communities Kralje, Journal of Sustainable Development Studies. 3(2)(2013)136-167.

[40] G. Rajović, J. Bulatović, Geographical View on Households: the Case Northeastern Montenegro, Open Journal of Social Science Research. 1(7)(2013) 169-173.

[41] M. Valdevit, Economic activity of the female population Croatian, Ekonomski pregled. 54 (910)(2003) 760-786.

[42] Statistical Office of Montenegro, Census of population, Households and Dwellings in 2003, Book 17, Podgorica, 2007.

[43] I. Đorđević, Changes in household average size in Serbia in the second half of the 20th century, Stanovništvo. 46(1)(2008) 41-69.

[44] Statistical Office of Montenegro, Census of population, Households and Dwellings in 2003, Book 10, Podgorica, 2006.

[45] N.V.Nimwegen, I. Esveldt, G. Beets, Population Trends and Family Policies in the, Children. 5(8) (2000) 11.

[46] A.Wertheimer -Baletić, Demographic Situation in Croatia-Current Demographic Processes, Diacovensia. 13(1)(2005) 97-118.

[47] J. Bongaarts, Human population growth and the demographic transition, Philosophical Transactions of the Royal Society B: Biological Sciences. 364(1532)(2009) 2985-2990.

[48] E. Vasilyeva, G. Theme, Efficiency Assessment of Regional Social and Demographic Process Management: Global Trends and Regional Specifics, In ERSA conference papers (No. ersa13p380) (2013), European Regional Science Association.

[48] G. Rajović, J. Bulatović, Traffic Infrastructure as Precondition Development Tourism on the Mountain Katuns: Example of Municipality Andrijevica. European Journal of Social and Human Sciences. 7(3)(2015) 150-162, 